\title{
Disappearance of gastrin and pentagastrin in the portal circulation
}

\author{
JOHN M. TEMPERLEY, BRIAN H. STAGG, AND JOHN H. WYLLIE \\ From the Department of Surgery and the Gastrointestinal Unit, University College Hospital Medical School, \\ London
}

SUMMARY Experiments on dogs and rats showed that synthetic human gastrin I was inactivated in the small bowel but not in the liver, whereas pentagastrin was rapidly inactivated by the liver. Similar results were obtained with tissue homogenates. The significance of these results is discussed in relation to the probably increased incidence of peptic ulceration following extensive small-bowel resection in man.

The physiological and pharmacological actions of the hormone gastrin and of its synthetic analogue pentagastrin ${ }^{1}$ have been extensively studied. Gastrin may be involved in the causation of peptic ulceration, and pentagastrin is now widely used as a gastric stimulant in tests of acid secretion, but little is known of the fate of either compound in the body. Since the blood concentration of a hormone or a drug depends on its rate of removal from the circulation as well as the rate at which it enters the circulation, it is important to study the fate of active substances in the body. For example, excessive levels of gastrin might be present in the blood even though the antrum secreted normal amounts; this could occur if the mechanism for removing gastrin were impaired. We have therefore devised experiments to investigate the inactivation of gastrin and pentagastrin by the liver and small bowel. In choosing to study the fate of these compounds in the portal circulation we were guided by the concept originally proposed by Elliott (1905) that hormones disappear in the tissues they excite. The experiments were performed on anaesthetized dogs and rats, and in vitro with homogenates of rat liver and small bowel mucosa.

\section{Methods}

\section{EXPERIMENTS IN DOGS}

Ten adult mongrel dogs weighing 6-16 kg were anaesthetized with intravenous pentobarbitone ( 25 $\mathrm{mg} / \mathrm{kg}$ body weight), and mechanically respired. In all the dogs wide bore cannulae were placed in the 'Peptavlon, ICI Ltd.

Received for publication 16 March 1971. pyloric antrum and the fundus of the stomach. Ligatures were tied around the pylorus and the oesophagus, care being taken in the latter case to exclude the vagi. During experiments the dog lay on its left side and the cannulae were placed so that fluid introduced into the pyloric cannula drained by gravity through the stomach and was all recovered from the fundal cannula. Fine polythene cannulae were placed in the left femoral and external jugular veins. In six dogs (group 1) a branch of the splenic vein was also cannulated, and the cannula was advanced till its tip lay in the portal vein. In four dogs (group II) we cannulated a branch of the superior mesenteric artery which supplied the first loop of jejunum. The cannula was passed retrogradely till its tip was felt to lie just within the main superior mesenteric artery.

In all animals, the femoral vein cannula was used for fluid replacement, and for further doses of pentobarbitone $(5 \mathrm{mg} / \mathrm{kg})$ which were given regularly every hour. A Watson Marlow MHRE Delta pump was used to infuse either synthetic human gastrin I (gastrin) or pentagastrin at constant submaximal rates (either 2 or $4 \mu \mathrm{g} / \mathrm{kg} / \mathrm{hr}$ ). Although these doses would be maximal for many conscious dogs, they were considered submaximal in our experiments since preliminary trial of $1 \mu \mathrm{g} / \mathrm{kg} / \mathrm{hr}$ in all the dogs gave either no secretion or very little. Only one dog required $4 \mu \mathrm{g} / \mathrm{kg} / \mathrm{hr}$. The site of infusion was changed at hourly intervals, between jugular and portal veins in group $I$, and jugular vein and superior mesenteric artery in group II. Five of the dogs in group I received gastrin infusions, and four received pentagastrin infusions. In group II only gastrin infusions were given. 
Acid secretion was measured for 40 minutes before commencing infusions, and during the infusions by washing out the stomach every 10 minutes with $20 \mathrm{ml}$ of $0.15 \mathrm{M}$ sodium chloride solution. Five $\mathrm{ml}$ of each collection was titrated to $p \mathrm{H} 7$ with $0 \cdot 1 \mathrm{~N} \mathrm{NaOH}$ using a Radiometer autotitrator and $p \mathrm{H}$ meter.

\section{EXPERIMENTS IN RATS}

Acid secretion in response to standard doses (50, 100 , or $150 \mathrm{ng}$ ) of either gastrin or pentagastrin was measured in 36 anaesthetized rats according to the technique described by Smith, Lawrence, ColinJones, and Schild (1970), except that during the preparation of the animals loose ligatures were placed round the superior mesenteric vessels. The basic technique involves the recirculation of $1.67 \mathrm{mM}$

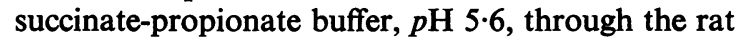
stomach and monitoring the $p \mathrm{H}$ change occurring in the buffer following injections of secretagogues via the jugular vein. Each animal received two of the standard doses, and acid secretion in response to each was measured. In half the rats, the ligatures were then tied, thus excluding the small bowel from the circulation; in the remaining rats the ligatures were left loose. The two standard doses of gastrin or pentagastrin previously given were then repeated in the same order, and the acid secretory responses were measured again.

\section{EXPERIMENTS in vitro}

Rats were killed by cervical dislocation and homogenates were prepared from the liver and the small bowel mucosa as follows. The tissue was homogenized in 5 volumes of $0.25 \mathrm{M}$ sucrose using a Potter-Elvejhem homogenizer. Large particles were deposited and discarded by centrifuging twice at $1800 \mathrm{~g}$ for $10 \mathrm{~min}$; smaller particles were discarded after centrifuging at $105,000 \mathrm{~g}$ for 60 minutes. The protein content of each homogenate was measured by the method of Lowry, Rosebrough, Farr, and Randall (1951) using crystalline bovine plasma albumen as standard.

To study the actions of homogenates on gastrin and pentagastrin, homogenate (diluted 10 times in some experiments) was incubated with gastrin or pentagastrin to give a final substrate concentration of $0.67 \mathrm{n} \mathrm{mol} / \mathrm{ml}(1.5 \mu \mathrm{g} / \mathrm{ml}$ for gastrin, $0.5 \mu \mathrm{g} / \mathrm{ml}$ for

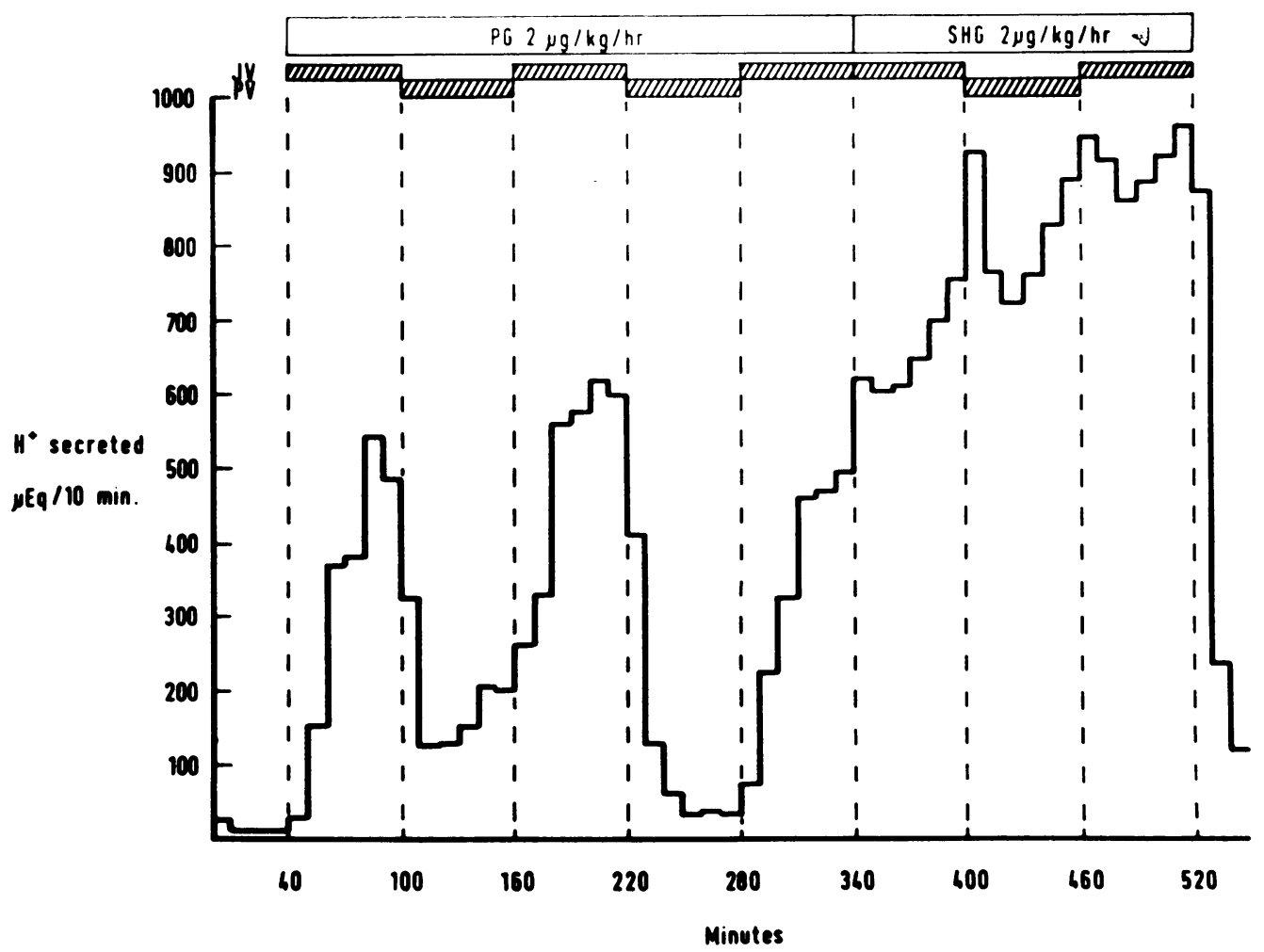

Fig. 1 Acid secretion ( $\mu$-equiv $\mathrm{H}^{+} / 10 \mathrm{~min}$ ) in an anaesthetized dog during infusions of pentagastrin $(P G)$ and synthetic human gastrin I (SHG) via the external jugular vein $(J V)$ and the portal vein $(P V)$. 


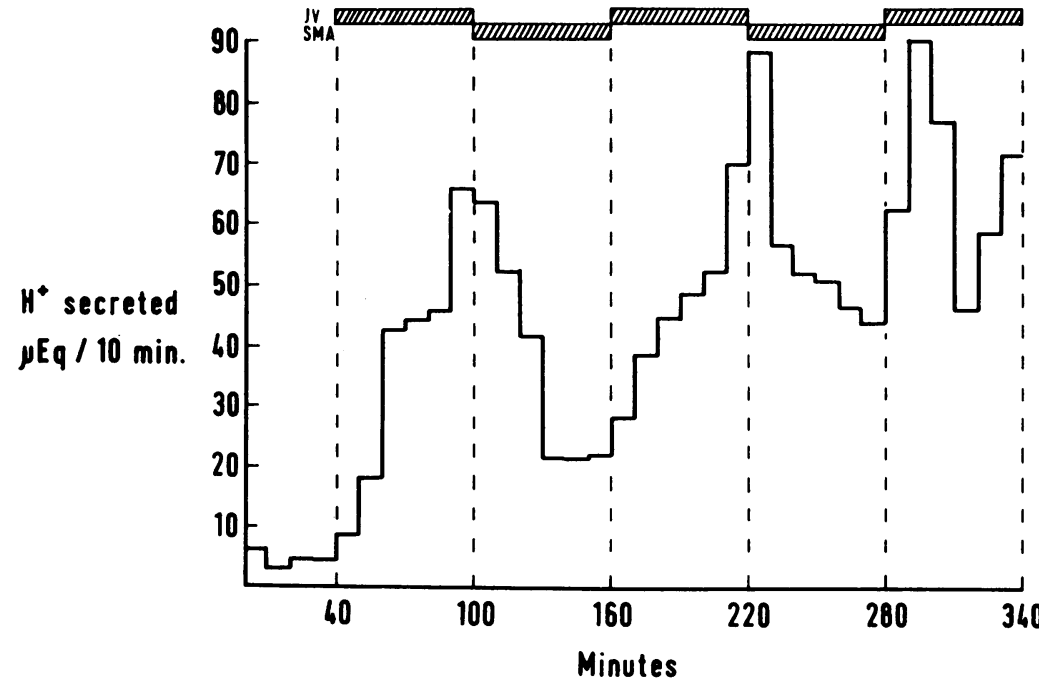

Fig. 2 Acid secretion ( $\mu$-equiv $\mathrm{H}^{+} / 10 \mathrm{~min}$ ) in an anaesthetized dog during infusions of synthetic human gastrin I $(2 \mu \mathrm{g} / \mathrm{kg} / \mathrm{hr})$ via the external jugular vein (JV) and the superior mesenteric artery $(S M A)$. pentagastrin). Control incubations were made with homogenate which had been boiled for five minutes and centrifuged to remove denatured protein. The incubates were sampled at intervals of five minutes for up to 30 minutes and the samples were immediately assayed in duplicate for gastrin-like activity (Smith et al, 1970).

\section{Results}

\section{ACID SECRETION IN DOGS}

In all dogs infusion of gastrin or pentagastrin produced an increase in acid secretion to more than 10 times the basal level. Typical experiments are shown in Figures 1 and 2. In the experiment shown in Fig. 1, pentagastrin was infused alternately into the jugular and portal veins for five hours, and then gastrin was similarly infused for three hours. Acid secretion rose when pentagastrin was infused into the jugular vein, and fell again to near basal levels when it was infused into the portal vein. Changing the site of gastrin infusions produced no such effect. Similar results were obtained in three other experiments with pentagastrin and in four other experiments with gastrin. Table I shows for these experiments the mean acid secretion in the last 30 minutes of infusions at different sites. During portal vein infusions of pentagastrin secretion was only $13 \%$ of that during jugular vein infusions of this substance $(\mathbf{P}<0.01)$. For gastrin, no significant difference emerged. Figure 2 shows that in another experiment acid secretion rose during jugular vein infusions of gastrin and fell during infusions into the superior mesenteric artery. Similar results were obtained in three further experiments. On average (Table I) mesenteric infusions produced only $63 \%$ of the secretion during jugular infusions $(P<0.01)$.

These results show that pentagastrin is almost completely inactivated by passage through the liver, whereas gastrin is unaffected. The potency of gastrin

\begin{tabular}{|c|c|c|c|c|c|c|c|}
\hline \multirow[t]{2}{*}{ Group ${ }^{1}$} & \multirow[t]{2}{*}{$\begin{array}{l}\text { No. of } \\
\text { Experiments }\end{array}$} & \multirow[t]{2}{*}{ Infusion } & \multicolumn{3}{|c|}{$\begin{array}{l}\text { Mean Acid Secretion ( } \mu \text {-equiv/30 min) during } \\
\text { Infusions into: }\end{array}$} & \multirow[t]{2}{*}{$\begin{array}{l}\text { Ratio of } \\
\text { Responses }\end{array}$} & \multirow[t]{2}{*}{$\mathbf{P}^{2}$} \\
\hline & & & Jugular Vein & Portal Vein & $\begin{array}{l}\text { Superior } M \\
\text { Artery }\end{array}$ & & \\
\hline $\begin{array}{l}\text { I } \\
\text { II }\end{array}$ & $\begin{array}{l}4 \\
5 \\
4\end{array}$ & $\begin{array}{l}\text { Pentagastrin } \\
\text { Gastrin } \\
\text { Gastrin }\end{array}$ & $\begin{array}{l}634 \cdot 6 \\
498 \cdot 6 \\
300 \cdot 8\end{array}$ & $\begin{array}{r}83 \cdot 2 \\
564.9 \\
-\end{array}$ & $\frac{-}{189 \cdot 4}$ & $\begin{array}{l}0.13 \\
1.13 \\
0.63\end{array}$ & $\begin{array}{l}<0.01 \\
\text { NS } \\
<0.01\end{array}$ \\
\hline
\end{tabular}

Table I Acid secretion in dogs receiving infusions of gastrin or pentagastrin

${ }^{1}$ In group I a comparison is made of the effect of infusing gastrin or pentagastrin alternately into the jugular and portal veins. In group $\mathbf{H}$ a similar comparison is made for gastrin infused alternately into the jugular vein and the superior mesenteric artery.

${ }^{2}$ The difference between the two treatment means was tested by a paired $t$ test on $\log$ values. 


\begin{tabular}{|c|c|c|c|c|c|c|c|}
\hline \multirow[t]{3}{*}{ Stimulant } & \multirow[t]{3}{*}{ Dose (ng) } & \multicolumn{3}{|c|}{ Mean Acid Secretion $\left(\mu E q H^{+}( \pm S E M)\right.$} & \multirow{2}{*}{\multicolumn{2}{|c|}{ Ligatures Tied }} & \multirow{3}{*}{$\mathbf{P}$} \\
\hline & & \multicolumn{2}{|l|}{ Control } & \multirow[t]{2}{*}{$\mathbf{P}$} & & & \\
\hline & & First Response & Second Response & & First Response & Second Response & \\
\hline Pentagastrin & $\begin{array}{r}50 \\
100 \\
150\end{array}$ & $\begin{array}{l}3.9 \pm 0.3 \\
5.6 \pm 0.5 \\
8.8 \pm 1.9\end{array}$ & $\begin{array}{l}3.8 \pm 0.3 \\
6.0 \pm 0.6 \\
8.6 \pm 1.5\end{array}$ & $\begin{array}{l}\text { NS } \\
\text { NS } \\
\text { NS }\end{array}$ & $\begin{array}{l}3.7 \pm 0.3 \\
4.8 \pm 0.5 \\
6.1 \pm 0.7\end{array}$ & $\begin{array}{l}4.1 \pm 0.5 \\
5.2 \pm 0.7 \\
6.3 \pm 0.6\end{array}$ & $\begin{array}{l}\text { NS } \\
\text { NS } \\
\text { NS }\end{array}$ \\
\hline Gastrin & $\begin{array}{r}50 \\
100 \\
150\end{array}$ & $\begin{array}{l}3.6 \pm 0.4 \\
5.8 \pm 0.4 \\
7.6 \pm 0.6\end{array}$ & $\begin{array}{l}3.5 \pm 0.4 \\
5.4 \pm 0.5 \\
7.3 \pm 0.5\end{array}$ & $\begin{array}{l}\text { NS } \\
\text { NS } \\
\text { NS }\end{array}$ & $\begin{array}{l}3.8 \pm 0.7 \\
5.0 \pm 0.6 \\
8.0 \pm 1.1\end{array}$ & $\begin{array}{r}5.9 \pm 0.5 \\
10.9 \pm 2.4 \\
11.5 \pm 1.4\end{array}$ & $\begin{array}{l}<0.01 \\
<0.05 \\
<0.01\end{array}$ \\
\hline
\end{tabular}

Table II Acid secretion of six rats receiving injections of pentagastrin or gastrin

is reduced by transit through the small bowel vascular bed.

\section{ACID SECRETION IN RATS}

In groups of six rats the mean acid secretory responses to $50 \mathrm{ng}, 100 \mathrm{ng}$, or $150 \mathrm{ng}$ of gastrin or pentagastrin were compared before and after ligation of the superior mesenteric vessels. Similar experiments were performed on control animals, in which the ligatures were not tied between responses. The results (Table II) show that there was no significant difference between responses in any of the control groups, or between responses to pentagastrin before and after ligation of the superior mesenteric vessels. In contrast, a significant rise in acid secretion occurred after mesenteric ligation in response to all three doses of gastrin. These results support the findings in the experiments on dogs with regard to gastrin and show that pentagastrin is not inactivated by the small bowel in the rat.

\section{EXPERIMENTS in vitro}

The rates of inactivation of pentagastrin and gastrin by homogenates of rat liver and small bowel mucosa are shown in Table III. Pentagastrin was rapidly

\begin{tabular}{lll}
\hline Tissue & \multicolumn{2}{l}{ Substrate } \\
\cline { 2 - 3 } & Gastrin & Pentagastrin \\
\hline Liver & 0.04 & 20.0 \\
Small-bowel mucosa & 0.90 & 0
\end{tabular}

Table III Rates of inactivation (nmol/min/mg tissue protein) of gastrin and pentagastrin by rat tissue homogenates

inactivated by liver, but was unaffected by small bowel mucosa. Gastrin was inactivated more than 20 times as rapidly by small bowel mucosa as by liver. No inactivation occurred when gastrin and pentagastrin were incubated with previously boiled homogenates. Similar results were obtained on at least two occasions for each incubation. These results in vitro show that rat liver and small bowel mucosa contain enzymes capable of inactivating pentagastrin and gastrin at very different rates, and are in keeping with the results of the experiments in vivo.

\section{Discussion}

The results of the experiments on dogs indicate that the biological activity of synthetic human gastrin I is unaffected by transit through the liver. They are in keeping with the results of Gillespie and Grossman (1962), Clarke, Hall, Devor, and Rizer (1967), Lick, Welsch, Hart, Bruckner, Balser, and Gurtner (1967) and McGuigan, Jaffe, and Newton (1970). Thompson, Reeder, Davidson, Charters, Bruckner, Lemmi, and Miller (1969) found that acid secretion from gastric fistulae in conscious dogs was similar during jugular vein and portal vein infusions of gastrin, but they found a $46 \%$ loss of gastrin across the liver when portal and hepatic vein levels were measured by radioimmunoassay. This suggests that there may be biologically active gastrin derivatives in the hepatic vein blood which are not immunoreactive. Such substances might be formed during hepatic transit by removal of amino-acid residues from the biologically inert $\mathrm{N}$-terminus of the gastrin molecule. LeVeen and Borek (1969) also suggested from their experiments on dogs that gastrin was metabolized by the liver, because injections of gastrin into the skin substitutes formed from small bowel (and therefore draining into the portal venous system) were less potent than similar injections into normal skin draining into the systemic veins. However, similar results would have been obtained if the small bowel itself, and not the liver, were inactivating gastrin. Our experiments show that the small bowel is indeed an important site of gastrin inactivation both in dogs and in rats. Osborne, Frederick, Sizer, Blair, Cole, and Thum (1966) have reported that extensive small bowel resection in man is followed by excessive acid secretion and a high incidence of peptic ulceration, 
which in some patients has proved fatal. They suggested that the small bowel produced an inhibitor of acid secretion, and that loss of this inhibitor after small bowel resection was the cause of the gastric hypersecretion. Our results cannot be interpreted in this way and they lead to the simpler explanation that gastrin is inactivated in the small bowel. Pentagastrin is not affected by the small bowel, at least in rats but it is rapidly inactivated by the liver.

The experiments in vitro support these observations and show that small-bowel homogenates rapidly inactivate gastrin but have no effect on pentagastrin, whereas liver homogenates inactivate pentagastrin very much more rapidly than gastrin. This means that the different potencies of gastrin and pentagastrin may be explained by their relative rates of metabolism and not by any intrinsic difference in their effects on the parietal cells.

It is evident that there are different enzymes in homogenates of liver and small-bowel mucosa which inactivate pentagastrin and gastrin respectively. Pentagstrin and gastrin have the same C-terminal tetrapeptide sequence in which all their biological activity appears to reside (Morley, Tracy, and Gregory, 1965). The biologically inactive part of the gastrin molecule (residues 1-13) is not, however, without function. Our experiments indicate that it protects the molecule from inactivation in the liver. Furthermore, it allows inactivation of gastrin in the small bowel and our experiments suggest that a specific enzyme exists in the small bowel to do this.

We thank Professor C. G. Clark and Dr J. E. Lennard-Jones for facilities and advice, Miss Lesley A. Gruby for technical assistance, and Dr J. S.
Morley (ICI Ltd) for gifts of gastrin and pentagastrin.

We are grateful to Mrs C. Howland of the MRC Statistical Research Unit, Gower Street, London WC1 for statistical advice; and to the Medical Research Council for financial assistance.

\section{References}

Clarke, J. S., Hall, R., Devor, D., and Rizer, J. (1967). Failure of gastrin inactivation by the liver. In Proceedings of the Internation Conference on Gastric Secretion, 'Mechanisms and control', pp. 357-361. Pergamon Press, London.

Elliott, T. R. (1905). The action of adrenalin. J. Physiol. (Lond.), 32, 401-467.

Gillespie, I. E., and Grossman, M. I. (1962). Gastric secretion of acid in response to portal and systemic venous injection of gastrin. Gastroenterology, 43, 189-192.

LeVeen, H. H., and Borek, B. (1969). Role of liver metabolism of gastrin in gastric secretion. (Abstr.), Fed. Proc., 28, 718.

Lick, R. F., Welsch, K. H., Hart, W., Bruckner, W., Balser, D., and Gurtner, T. (1967). Zur sekretorischen Funktion des Magens nach Injektion von Histamin, Gastrin und synthetischen Tetrapeptid in den grossen Kreislauf und in die Pfortader. Z. Gastroent., 5, 7-12.

Lowry, O. H., Rosenbrough, N. J., Farr, A. L., and Randall, R. J. (1951). Protein measurement with the folin phenol reagent. J. Biol. Chem., 193, 265-275.

McGuigan, J. E., Jaffe, B. M., and Newton, W. T. (1970). Immunochemical measurements of endogenous gastrin release. Gastroenterology, 59, 499-504.

Morley, J. S., Tracy, H. J., and Gregory, R. A. (1965). Structurefunction relationships in the active C-terminal tetrapeptide sequence of gastrin. Nature (Lond.), 207, 1356-1359.

Osborne, M. P., Frederick, P. L., Sizer, J. S., Blair, D., Cole, P., and Thum, W. (1966). Mechanism of gastric hypersecretion following massive intestinal resection. Clinical and experimental observations. Ann. Surg., 164, 622-632.

Smith, G. M., Lawrence, A. J., Colin-Jones, D. G., and Schild, H. O. (1970). The assay of gastrin using the perfused rat stomach. Brit. J. Pharmacol., 38, 206-213.

Thompson, J. C., Reeder, D. D., Davidson, W. D., Charters, A. C., Bruckner, W. L., Lemmi, C. A. E., and Miller, J. H. (1969). Effect of hepatic transit of gastrin, pentagastrin and histamine measured by gastric secretion and by assay of hepatic vein blood. Ann. Surg., 170, 493-503. 